\title{
ELECTRONIC ANNUAL PERFORMANCE EVALUATION REPORT SYSTEM AND EMPLOYEE PERFORMANCE IN FEDERAL ROAD SAFETY CORPS, ABA
}

\author{
Onyema, Chiemeka \\ Phd, Department of Sociology \\ Imo State University, \\ Owerri, Imo State, \\ Nigeria.
Okoli, Anthony Okwuchukwu
Department of Sociology,
Imo State University,
Owerri, Imo State, Nigeria.

\begin{abstract}
This work examined the impact of electronic annual performance evaluation report system on employee performance in Federal road safety corps, Aba, in Abia State, Nigeria. The survival of any organization is dependent on the strategies designed and adopted in coping with internal and external challenges. One of such measures is to keep the staff alive to their responsibilities, with the aim of increasing productivity. Organizations develop measures to rate their staff so as to reward or punish as occasion may demand. The Electronic Annual Performance Evaluation Report System (e-APERS) is one of such measures used to analyze an employee's annual successes and failures, personal strengths and weaknesses, and suitability for promotion or further training. The procedural justice theory was adopted as the framework of this research. The survey research design was adopted, the area of the study is federal road safety corps, Aba. The researcher adopted the total population sampling technique, the researcher gathered data using questionnaire. Data were presented using simple percentages and tables. Hypothesis was tested using the chi-square $\left(\mathrm{X}^{2}\right)$ statistical tool. The hypothesis which states that; there is a significant relationship between electronic annual performance evaluation report system and employee attendance to work tested positive, The study found that electronic annual performance evaluation report system has affected employee attendance to work positively. The study recommend that management should introduce post appraisal counseling where the appraisal outcomes are analyzed to explain strengths and weaknesses and set agenda for better future performance. Keywords-Appraisal, Performance, Employee, Evaluation
\end{abstract}

\author{
Iwu, Uchenna Okechukwu \\ Department of Sociology, \\ Imo State University, \\ Owerri, Imo State, \\ Nigeria.
}

\author{
Ikechukwu, Ogbonna \\ Federal University of Technology, \\ Owerri, Imo State, Nigeria.
}

\section{INTRODUCTION}

The survival of any organization is dependent on the strategies designed and adopted in coping with internal and external challenges. One of such measures is to keep the staff alive to their responsibilities, with the aim of increasing productivity. Organizations develop measures to rate their staff so as to reward or punish as occasion may demand. The Electronic Annual Performance Evaluation Report System (eAPERS) is one of such measures used to analyze an employee's annual successes and failures, personal strengths and weaknesses, and suitability for promotion or further training.

Human resource management focuses on personnel related areas such as job design, resource planning, recruitment, selection, compensations, employee relations and performance appraisal system. The appraisal of employee is usually carried out annually using performance evaluation system. According to Giddens (2016), performance appraisal is a tool of management, a control process, a critical element in human resource allocation and many others. For Adeleye (2015), performance appraisal is a systematic general and periodic process that assesses an individual employee's job performance and productivity in relation to certain preestablished criteria and organizational objectives. To collect performance appraisal data, there are three main methods: objective production, personnel, and judgemental evaluations are the most commonly used with a large variety of evaluation methods.

Electronic annual performance evaluation report system is a formal structured system of measuring and evaluating an employee's job related skills and outcomes to discover how and why the employee is presently performing 


\section{International Journal of Engineering Applied Sciences and Technology, 2019 \\ Vol. 4, Issue 7, ISSN No. 2455-2143, Pages 73-79 \\ Published Online November 2019 in IJEAST (http://www.ijeast.com)}

on the job and how the employee can perform more effectively in the future so that the employee, organization and society benefits. In FRSC e-annual performance evaluation report system was used to manage, align all its personnel in order to achieve highest possible performance. However, how performance is managed in an organization determines to a large extent the success or failure of that organization. Therefore, improving e-annual performance evaluation system for everyone should be among the highest priorities of contemporary organizations.

According to Etim, Shola and Taiwo (2016), the most successful organizations in the $21^{\text {st }}$ century are those who adopt a focused and integrated annual performance evaluation system. The enormous transformation processes that take place in the social, political and economic areas drive the need for organizations to be more responsive to the rapid development of the global strategies and the local operational levels. Within the Federal Road Safety Corps, one function plays a critical role for the global success of the organization, and this is performance evaluation. Employee performance has emerged as a potential important employee engagement and organizational management subject (Endres 2014). Employee performance therefore remains the most prominent and valuable tool. It is this reason electronic annual performance evaluation report system is given recognition as a tool to improve employee performance. Employee performance is defined as whether a person executes their assigned duties and responsibilities well. An engaged employee is aware of the job ethics, and works with colleagues to improve performance within the job for the benefit of the organization. Thus, many organizations assess their employee performance on annual or quarterly basis in order to define certain area that needs improvement. Employee performance is a critical factor in organizational success.

In 2014, the Federal Road Safety Corps, a paramilitary agency that manages road safety in Nigerian adopted electronic annual performance evaluation system to appraise its personnel. E-annual performance evaluation report system is the annual evaluation report whereby employee's work ethics, skills and capabilities are assessed for the suitability of promotion and training (David, 2008). E-annual performance evaluation report system has been considered as the most significant and indispensible tool in the Corps, because the information it provides is highly useful in making decisions regarding various personnel aspects such as promotion and merit benefits as well as punishment. Hence, this study is designed to investigate the effects of electronic annual performance evaluation report system on employee performance in Federal Road Safety Corps Aba, Abia State, Nigeria.

\section{OBJECTIVE OF THE STUDY}

- To examine whether electronic annual performance evaluation report system has led to staff attendance to work (punctuality).

\section{HYPOTHESIS}

- There is a significant relationship between electronic annual performance evaluation report system and employees' attendance to work.

\section{LITERATURE REVIEW AND THEORETICAL FRAMEWORK}

\section{Concept of Electronic Annual Performance Evaluation} Report System

According to Jonas (2016) electronic annual performance evaluation report system is a means of measuring or assessing employees' achievements within a stated period of time using reliable measurement criteria with the ultimate goal of providing information to superiors on how to improve employees' effectiveness. There are tons and wide range of literature on performance evaluation. Ataka (2003) argues that e-annual performance evaluation report is a systematic and holistic process of work, planning, monitoring and measurement aimed at continuously improving the teams and individual employee's contribution to achievement of organizational goals. This depicts that performance appraisal is used as a means of establishing future goals, monitoring employees' progress based on specific job description, and measuring performance, teamwork and achievements based on specified tasks that can be linked with organizational goals and objectives. Furthermore, performance evaluation is used to formally determine employees' performance (Ikramullah, Yusuf and Garba 2013). In addition, Fletcher (2001) opined performance evaluation as a means by which organizations develop competency, improve employee motivation and achieve equitable allocation of resources. In essence, performance appraisal achieves a multiple purpose from measurement to motivation and resource allocation. As noted by Cleverland, Murphy and Williams (2008), performance evaluation system can be used to motivate employees through remuneration, promotions, retrenchment, and the improvement of skills, competence and expertise. In addition, performance evaluation can be said to be a process of measuring employees contribution which turns out to be beneficial, both to the staff and the organization at large if carried out properly.

According to Bassey, Esu and Iyang (2009), performance appraisal system is a means of investigating employee achievement over a certain period of time for achieving organizational goals. Consequently, performance evaluation is a means of knowledge sharing among subordinates and superiors to adequately measure the progress of the employee which will aid in making strategic human resource decisions. He further stressed that the institutionalization of performance evaluation system started as far back as the industrial revolution when it was used as a means of measuring organizational efficiency. Wren (2004) affirmed that performance evaluation was incepted when Robert Owen used wooden coloured block to measure the achievement of employees working in the cotton mills in Scotland at the close of work hours. During that era, it was 


\section{International Journal of Engineering Applied Sciences and Technology, 2019 \\ Vol. 4, Issue 7, ISSN No. 2455-2143, Pages 73-79 \\ Published Online November 2019 in IJEAST (http://www.ijeast.com)}

utilized as a disciplinary mechanism for punishing poor performance (Kennedy and Dresser, 2001). This resulted in the negative notation of the evaluation system which turned out to be despised by both the appraiser and the appraisee. Performance evaluation is a yearly rite of passage in organizations that trigger strength and apprehension in the most experienced, battle hardened manager". The above quote summarizes the extent to which the evaluation process is disliked by the evaluators. Subsequently, organizations tried to refine the methods linking it to other administrative matters including reward, promotion, training, demotion and so forth, arguing that employee's achievements should not only be measured but evaluated and managed (Kennedy and Dresser 2001). The e-annual performance evaluation report system emerged as a systematic and holistic process of monitoring employees expected job deliverables and targets.

Electronic Annual Performance Evaluation Report System and Employee Performance

According to Adeleye (2015), maximizing the performance of organization is the main issue for an organization. Good organization performance refers to the employee's performance. Satisfactory performance of employees does not happen automatically. Managerial standards, knowledge, skills, commitment and performance appraisal affects employees' performance.

Endress (2014), is of the opinion that performance appraisal is very important process, but deemed to be the "weak point" of managing human force. Olaoluwa (2015) sees performance as behavior the way in which organization's teams and individuals get work done. He went further to assert that performance is not only peculiar to results, but that if also relates with and behaviors of employees that they adopted to achieve their given goals. Jordan (2014) argues that e-annual performance evaluation system is important for staff commitment, motivation, attitude and behavior development, communicating organizational aims, and fostering positive relationships between management and staff. For him, annual performance evaluation report system provides a formal, recorded, regular review of an individual's performance, and a plan for future development. In short, performance and job appraisals are vital for managing the performance appraisal and employees' commitment.

Cleverland, Murph and Williams (2008) stated that there are two types of performance appraisal which they referred to as traditional form of appraisal and non-traditional form. According to them, the traditional form of appraisal is also known as "free form method". This form of appraisal involves the overseeing and description of employee performance by his boss or superior. They also opined that non-traditional form of appraisal is common in practices. They asserted that these techniques are mostly used throughout the world for appraisal method and they include;
i. Assessment centre.
ii. Behaviourally anchored scales (BARS)
iii. Human resources accounting method

\section{iv. $\quad 360$ degree performance appraisals \\ v. Management by objectives (MBO)}

According to them, assessment centre involves the informal events, test and assignment that are given to the group of employees to evaluate their competencies. Behaviorally, an anchored rating scale is new method that consists of predetermined critical areas of performance or it is set of behaviors statements that describe important job qualities what is good and what is bad. For them, in human resources accounting method, performance is evaluated based on term of contribution and cost of employees. 360 degree involves the feedback of employee's performance by anyone who has contact with employee in organization. In 360 degree, includes self-appraisal, superior appraisal, subordinate appraisal, peer appraisal. For them, these methods are less structured than the traditional method which focuses less on the ranking and ratings, and more emphasis on arranging meetings between employees and supervisors. Agba (2002) argue that performance is an outcome, or result of an individual's actions. An individual's performance therefore becomes a function of ability and motivation. To him, performance assessment (also performance appraisal, evaluation, measurement) becomes a continual review of the job related task accomplishment or failures of the individuals within the organization. A major consideration in performance improvement involves the creation and use of performance measures or indicators; which are measureable characteristics of products, services, processes and operations the commission uses to track and improve performance.

Shelley (2015) describes performance appraisal as the process of obtaining, analyzing and recording information about the relative worth of an employee. The focus of the performance appraisal is measuring and improving the actual performance of the employee and also the future potential of the employee. Its aim is to measure what an employee does. Shelley again considers APERS as a systematic way of reviewing and assessing the performance of an employee during a given period of time and planning for his future. It is a powerful tool to calibrate, refine and reward the performance of the employee. Collins (2016) corroborated David (2008) position and further add that performance appraisal is a process by which organization evaluate employee performance based on preset standards. Collins describes the main purpose of appraisal as helping managers effectively staff companies and use human resources, and, ultimately, improving productivity. According to Collins (2016) when conducted properly, appraisals serves the purpose Shelley describes by; (i) showing employees how to improve their performance, (ii) setting goals for employees and (iii) helping managers to assess subordinates' effectiveness and take actions related to hiring, promotions, demotions, training, compensation, job design, transfers and termination of appointments. 


\section{International Journal of Engineering Applied Sciences and Technology, 2019 \\ Vol. 4, Issue 7, ISSN No. 2455-2143, Pages 73-79 \\ Published Online November 2019 in IJEAST (http://www.ijeast.com)}

The above expositions given by Collins and Shelley collectively establish performance appraisal as a clear and concise, regular and unbiased system of rating an employee's performance in her current position, which can also be used to determine how far the employee can go in career development. The benchmarks of such an appraisal, according to Collins, are usually the job description in tandem with stated company objectives, and often include rewards and incentives. An organization engages a person for the purpose of employing his skills to achieve certain goals and objectives. Every so often, the employer needs to take stock and determine the value of each employee, his potential, and what his future in the company is likely to be.

Collins (2016) also identifies some objectives of performance appraisal as indicated below;

i. To review the performance of the employees over a given period of time.

ii. To judge the gap between the actual and desired performance.

iii. To help the management in exercising organizational control.

iv. Helps to strengthen the relationship and communication between superior-subordinates and management-employees.

v. To diagnose the strengths and weaknesses of the individuals so as to identify the training and development needs of the future.

vi. To provide feedback to the employees regarding their past performance.

vii. Provide information to assist in the other personal decisions in the organization.

viii. Provide clarity of the expectations and responsibilities of the functions to be performed by the employees.

ix. To judge the effectiveness of the other human resources functions of the organization such as recruitment, selection, training and development.

$\mathrm{x}$. To reduce the grievance of the employees.

The researcher adopted the procedural justice theory in explaining this work. This theory holds that employees are going to be more motivated to perform their assigned duties when they find out that the process used to evaluate their job functions and skills are accurate, trusted and fair. According to this theory, an employee tends to be more involved in carrying out his/her duties, when the appraisal system/method is free from bias. Also, if workers think they are being shortchanged, it may affect their feelings towards the organization, which might lead to a decrease in workers job performance. This theory therefore clearly explains the study under focus and best fits. This is because the more committed employees are in an organization, the higher the level of performance of such organization. Thus, according to this theory, employers should be fair and just in appraising their employees so that they will put in more efforts and show high level of performance and commitment in the growth of the organization.

The researchers adopted the procedural justice theory in explaining this work. This theory holds that employees are going to be more motivated to perform their assigned duties when they find out that the process used to evaluate their job functions and skills are accurate, trusted and fair. According to this theory, an employee tends to be more involved in carrying out his/her duties, when the appraisal system/method is free from bias. Also, if workers think they are being shortchanged, it may affect their feelings towards the organization, which might lead to a decrease in workers job performance. This theory therefore clearly explains the study under focus and best fits. This is because the more committed employees are in an organization, the higher the level of performance of such organization. Thus, according to this theory, employers should be fair and just in appraising their employees so that they will put in more efforts and show high level of performance and commitment in the growth of the organization.

\section{METHODOLOGY}

The research design for this study is survey research design. Survey research design means the investigation of the behavior, opinion or other manifestations of a group of people by questioning them. The researcher adopted the survey research design because of its flexible to permit the use of a variety of data collection techniques. Also, survey research design sensitizes the researchers to potential problems that were originally unknown.

The area of this study is Federal Road Safety Corps Aba. Federal Road Safety Corps is the government agency with statutory responsibilities for road safety administration in Nigeria. Founded in February 1988, it is established by law the FRSC operates in all Nigerian States as well as federal capital territory (FCT) Abuja. FRSC is currently headed by Dr. Boboye Oyeyemi whose title is the Corps Marshal, the highest rank in the Corps ranking system. The statutory functions of FRSC includes making highways safe for motorist and other road users, as well as checking road worthiness of vehicles, recommending works and infrastructure to eliminate or minimize accidents on the highways and educating motorists and members of the public on the importance of road discipline on the highways. Road safety, as one of the paramilitary agencies in Nigeria has its own method of appraising its employees in operation. This method is referred to as electronic annual performance evaluation report system (e-APERS).

The Corps has two arms of personnel who drive its activities; Regular Marshals and Special Marshals. Regular Marshals are uniformed personnel, permanently paid and pensionable unlike Special Marshals whose services are voluntary in nature. The "Regular" as the name implies, indicates that the Marshal is duty bound to be regular in the discharge of its statutory duties. One of the primary features of a regular marshal is that they serve as public relation officers; 


\section{International Journal of Engineering Applied Sciences and Technology, 2019 \\ Vol. 4, Issue 7, ISSN No. 2455-2143, Pages 73-79 \\ Published Online November 2019 in IJEAST (http://www.ijeast.com)}

in order words they portray the image of the Corps to the public. The Corps has a greater number of male than female employed. We have different cadre in FRSC such as Officers' cadre and Marshals' cadre. Officers' cadre ranges from;

Table 1: Showing Rank of Officers

\begin{tabular}{|c|c|}
\hline $\begin{array}{l}\text { Officers Cadre Rank } \\
\text { Acronyms }\end{array}$ & Rank Full Meaning \\
\hline ARC & $\begin{array}{l}\text { Assistant Route Commander (Entry } \\
\text { Point) }\end{array}$ \\
\hline DRC & Deputy Route Commander \\
\hline $\mathrm{RC}$ & Route Commander \\
\hline SRC & Superintendent Route Commander \\
\hline $\mathrm{CRC}$ & Chief Route Commander \\
\hline $\mathrm{ACC}$ & Assistant Corps Commander \\
\hline DCC & Deputy Corps Commander \\
\hline $\mathrm{CC}$ & Corps Commander \\
\hline $\mathrm{ACM}$ & Assistant Corps Marshal \\
\hline DCM & Deputy Corps Marshal \\
\hline $\mathrm{CM}$ & Corps Marshal \\
\hline & Marshals' Cadre \\
\hline RMAIII & $\begin{array}{l}\text { Road Marshal Assistant III (Entry } \\
\text { point) }\end{array}$ \\
\hline RMAII & Road Marshal Assistant II \\
\hline RMAI & Road Marshal Assistant I \\
\hline SRMA & Senior Road Marshal Assistant \\
\hline DCRMA & $\begin{array}{llll}\text { Deputy Chief } & \text { Road } & \text { Marshal } \\
\text { Assistant } & & & \\
\end{array}$ \\
\hline CRMA & Chief Road Marshal Assistant \\
\hline MI-III & Marshal Inspector III \\
\hline MI-II & Marshal Inspector II \\
\hline MI-I & Marshal Inspector I \\
\hline SMI & Senior Marshal Inspector \\
\hline PMI & Principal Marshal Inspector \\
\hline $\mathrm{ACI}$ & Assistant Chief Inspector \\
\hline DCI & Deputy Chief Inspector \\
\hline $\mathrm{CI}$ & Chief Inspector \\
\hline
\end{tabular}

Source: (Administrative and Human Resources department of FRSC Aba.)

The population consists of personnel of Federal Road Safety Corps Aba which is three hundred and sixty-three (363). The researcher chose $100 \%$ of the respondents which is the total population under study. The respondents were drawn from seven (7) departments that made up FRSC Aba.

Table II: Showing departments and their sample size proportion.

\begin{tabular}{|l|l|c|}
\hline No & Department & No of Staff \\
\hline 1. & $\begin{array}{l}\text { Administration \& Human } \\
\text { Resources }\end{array}$ & 48 \\
\hline 2. & Operations & 89 \\
\hline 3. & Policy, Research and Statistics & 43 \\
\hline 4. & Motor Vehicle Administration & 45 \\
\hline 5. & Medical \& Rescue Services & 43 \\
\hline 6. & Training & 44 \\
\hline
\end{tabular}

\begin{tabular}{|l|l|c|}
\hline 7. & $\begin{array}{l}\text { Public Education \& } \\
\text { Enlightenment }\end{array}$ & 51 \\
\hline & TOTAL & $\mathbf{3 6 3}$ \\
\hline
\end{tabular}

Source: (Administrative and Human Resources department of FRSC Aba.)

The researcher adopted total population sampling technique. This is because it helps the researcher to get deep insights into the phenomenon under study. Data were collected using questionnaire. Data were presented using simple percentages and tables, while the research hypotheses were tested using the chi-square $\left(\mathrm{X}^{2}\right)$ statistical tool. This is because it gives the opportunity to establish relationship between variables.

\section{RESULT AND DISCUSSION}

Table III Distribution of questionnaire

\begin{tabular}{|l|l|l|l|l|l|}
\hline S/N & Department & $\begin{array}{l}\text { Questi } \\
\text { onnaire } \\
\text { distrib } \\
\text { uted }\end{array}$ & $\begin{array}{l}\text { Questionnair } \\
\text { e returned }\end{array}$ & $\%$ \\
\hline 1 & $\begin{array}{l}\text { Administration \& } \\
\text { Human Resources }\end{array}$ & 48 & 100 & 48 & 100 \\
\hline 2 & Operations & 89 & 100 & 89 & 100 \\
\hline 3 & $\begin{array}{l}\text { Policy, Research } \\
\text { and Statistics }\end{array}$ & 43 & 100 & 43 & 100 \\
\hline 4 & $\begin{array}{l}\text { Motor Vehicle } \\
\text { Administration }\end{array}$ & 45 & 100 & 45 & 100 \\
\hline 5 & $\begin{array}{l}\text { Medical \& } \\
\text { Rescue Services }\end{array}$ & 43 & 100 & 43 & 100 \\
\hline 6 & Training & 44 & 100 & 44 & 100 \\
\hline 7 & $\begin{array}{l}\text { Public Education } \\
\& \text { Enlightenment }\end{array}$ & 51 & 100 & 51 & 100 \\
\hline & Total & 363 & 100 & 363 & 100 \\
\hline
\end{tabular}

$\%$ frequency distributed $=\underline{\text { No of questionnaire distributed } \times 100}$ Total questionnaire distributed

$\%$ frequency returned $=\underline{\text { No of questionnaire returned } \times 100}$ Total questionnaire returned

The above table shows that 363 set of questionnaires was distributed among the personnel in federal Road Safety Corps Aba, Abia State, Nigeria, the researcher was able to retrieve the same number of question distributed which is 363 , which eventually forms the sample size for this study. 


\section{International Journal of Engineering Applied Sciences and Technology, 2019 \\ Vol. 4, Issue 7, ISSN No. 2455-2143, Pages 73-79 \\ Published Online November 2019 in IJEAST (http://www.ijeast.com)}

Table IV Electronic Annual Performance Evaluation System and Employees Attendance to Work.

\begin{tabular}{|c|c|c|c|c|c|}
\hline $\begin{array}{l}\text { Item } \\
\mathrm{s}\end{array}$ & Questions & Positive & $\begin{array}{l}\text { Negativ } \\
\text { e }\end{array}$ & $\%$ & $\begin{array}{l}\text { Total } \\
\text { samp } \\
\text { le }\end{array}$ \\
\hline 1 & $\begin{array}{l}\text { Electronic } \\
\text { evaluation } \\
\text { employees has led } \\
\text { to } \\
\text { increased } \\
\begin{array}{l}\text { attendance } \\
\text { work? }\end{array}\end{array}$ & $\begin{array}{l}363(100 \\
\%)\end{array}$ & - & 100 & 363 \\
\hline 2 & $\begin{array}{l}\text { Workers are scared } \\
\text { of coming late to } \\
\text { work due to the } \\
\text { electronic } \\
\text { evaluation report? }\end{array}$ & $\begin{array}{l}361(99.4 \\
\%)\end{array}$ & $2(0.6 \%)$ & 100 & 363 \\
\hline 3 & $\begin{array}{l}\text { Despite the } \\
\text { electronic } \\
\text { evaluation report } \\
\text { system workers } \\
\text { still come late to } \\
\text { work. }\end{array}$ & $3(0.8 \%)$ & $\begin{array}{l}360(99 . \\
2 \%)\end{array}$ & 100 & 363 \\
\hline 4. & $\begin{array}{l}\text { Employees may be } \\
\text { punctual to work if } \\
\text { they discover that } \\
\text { the electronic } \\
\text { evaluation report } \\
\text { system is fair and } \\
\text { unbiased? }\end{array}$ & $\begin{array}{l}350(96.4 \\
\%)\end{array}$ & $\begin{array}{l}13(3.6 \\
\%)\end{array}$ & 100 & 363 \\
\hline 5. & 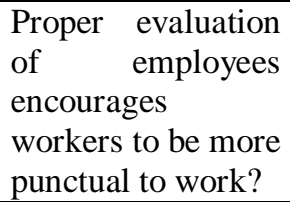 & $\begin{array}{l}362(99.7 \\
\%)\end{array}$ & $1(0.3 \%)$ & 100 & 363 \\
\hline
\end{tabular}

The table above shows that $100 \%, 99.4 \%, 0.8 \%, 96.4 \%$ and $99.7 \%$ responded positively to items $1,2,3,4$ and 5 , while $0 \%$, $0.6 \%, 99.2 \%, 3.6 \%$ and $0.3 \%$ responded negatively to items $1,2,3,4$ and 5 respectively.

Table V Chi-square Analysis for Electronic Annual Performance Evaluation Report System and Employees Attendance to Work.

\begin{tabular}{|c|c|c|c|c|c|}
\hline Items & SA & A & D & SD & TOTAL \\
\hline 1 & 300 & 50 & 3 & 10 & $363 \mathrm{~B}_{1}$ \\
& & & & & \\
\hline 3 & 3 & - & 59 & 301 & $363 \mathrm{~B}_{2}$ \\
\hline 5 & 302 & 58 & - & 3 & $363 \mathrm{~B}_{3}$ \\
\hline Total & $\begin{array}{c}605 \\
\mathrm{~A}_{1}\end{array}$ & $\begin{array}{c}110 \\
\mathrm{~A}_{2}\end{array}$ & $62 \mathrm{~A}_{3}$ & $314 \mathrm{~A}_{4}$ & 1089 \\
& & & \\
\hline
\end{tabular}

The table value of $\mathrm{x}^{2}$ at a significance level of 0.05 and degree of $3=7.815$. The calculated value of $x^{2}=21.5$. Since the calculated value of $x^{2}$ is greater than the table value of $x^{2}$, we therefore accept the hypothesis which states that there is a significant relationship between annual performance evaluation report system and employees attendance to work.

\section{Discussion of findings}

Based on the research carried out on Electronic Annual Performance Evaluation Report System and Employees Performance in FRSC Aba, Abia State, Nigeria, the researcher found out that;

Electronic annual performance evaluation report system has improved employees attendance to work. This is in line with the postulation of Akajiaku (2016) that the reason some employees come to work regularly is for them to score high in the evaluation process. This is also in line with item one in table $4.1 .8,363(100 \%)$ of the respondents agreed that electronic evaluation of employees has led to workers increased attendance to work.

\section{CONCLUSION}

The electronic annual performance evaluation report system has positively affected employees' performance as personnel of the federal road safety corps are now coming to work very early and regularly, as it has also affected their promotion, which has eventually made them to become more committed to their assigned duties.

\section{Recommendation}

The study recommend that management should introduce post appraisal counseling where the appraisal outcomes are analyzed to explain strengths and weaknesses and set agenda for better future performance.

\section{REFERENCE}

[1] Adeleye O (2015). Social change and organizational performance. Ibadan: Adeoti publishers. (pp 45-56).

[2] Agba M. (2002). Collective bargaining, negotiations and agreement. Ibadan: Mosi and Moyo Publishers. (pp 212217)

[3] Ataka A. (2003). Motivation and employee job performance in Nigeria. Uyo: Ubong publishers. (pp 2432).

[4] Basey E., Esu N and Iyang J. (2009). Concept of performance appraisal and employees motivation. Abeokuta: Ade Publishers. ( pp 665-668).

[5] Cleverland C., Murphy A., and Williams M.(2008) Understanding human behaviour in organizations. London: McGraw hill publishers. ( pp 773-779)

[6] Collins W. (2016). Performance appraisal and workers engagement. Abeokuta: Muyiwa publishing Co. Ltd. (pp 410-418)

[7] David S. (2008). Organizational Evaluation Process and Employee Performance. Ikare: Olawale Printing Press. (pp. 345-354). 
[8] Endress R. (2014). Training and Employee Job Performance. Santiago: Isco Publishers. (pp 111-118).

[9] Etim C., Shola A., and Taiwo S. (2016). Organizational Culture and Behaviour. Journal of Sociological Studies. 5(10) (Pp 32-36).

[10] Fletcher R. (2001). The Practice of Management. London: Rodney Publishers. (pp 12-16).

[11] Giddens A.(2016). Sociology $7^{\text {th }}$ Edition. New Delhi: John Willey and Sons Inc. (pp 44-49).

[12] Ikramullah Q., Yussuf G., and Garba H. (2013). Personnel and Human Resources Management. New Jersey: Prentice Hall. (pp. 23-27)

[13] Jonas F. (2016). Industrial Democracy and Productivity of Workers in the Imo State Civil Service. Unpublished M.Sc Dissertation, Imo State University, Owerri. (pp. 3136)

[14] Jordan C. (2014).Society, Industry and Development. Journal of Social Science Research. 7(6). (pp 66-71).

[15] Kennedy S., and Dresser O. (2001) Introduction to Human Resource and Personnel Management. Chicago: Living Stone Publishers. ( pp 56-68).

\section{ACKNOWLEDGEMENTS}

We are greatful to Prof Osita-Njoku Agnes and Daniel Ibeawuchi Nkwocha for the help they rendered during the course of this work. We also acknowledge all the authors that their works were cited in this research. 